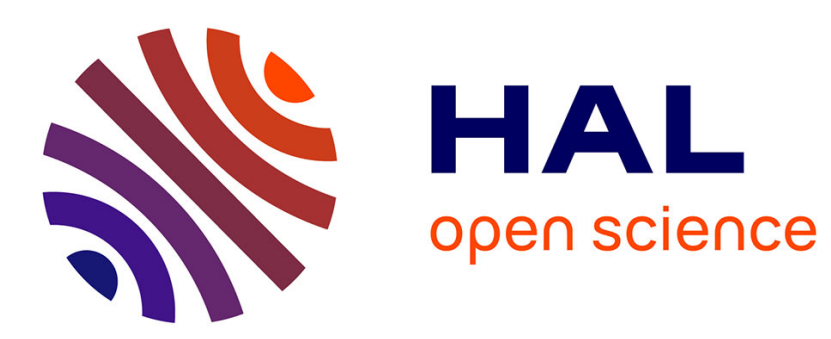

\title{
Use of wax emulsions for improvement of wood durability and sorption properties
}

\author{
Boštjan Lesar, Miha Humar
}

\section{To cite this version:}

Boštjan Lesar, Miha Humar. Use of wax emulsions for improvement of wood durability and sorption properties. European Journal of Wood and Wood Products, 2010, pp.231-238. 10.1007/s00107-0100425-y . hal-00594485

\section{HAL Id: hal-00594485 \\ https://hal.science/hal-00594485}

Submitted on 20 May 2011

HAL is a multi-disciplinary open access archive for the deposit and dissemination of scientific research documents, whether they are published or not. The documents may come from teaching and research institutions in France or abroad, or from public or private research centers.
L'archive ouverte pluridisciplinaire HAL, est destinée au dépôt et à la diffusion de documents scientifiques de niveau recherche, publiés ou non, émanant des établissements d'enseignement et de recherche français ou étrangers, des laboratoires publics ou privés. 


\title{
Use of wax emulsions for improvement of wood durability and sorption properties
}

\author{
Boštjan LESAR and Miha HUMAR* \\ University of Ljubljana, Biotechnical Faculty, Department for wood science and \\ technology \\ Jamnikarjeva 101, SI 1000 Ljubljana, Slovenia \\ miha.humar@bf.uni-lj.si
}

\begin{abstract}
:
Waxes are used for treatment of wood surfaces for several decades predominately as surface treatments because they weakly penetrate into the wood. In order to overcome this issue, water emulsions were applied in the present experiment. Five water emulsions of various concentrations were used, namely montan wax, polyethylene, ethylene copolymer and oxidized polyethylene wax. Performance of wax treated beech (Fagus sylvatica) and Norway spruce (Picea abies) against white rot, brown rot and blue stain fungi was tested. In parallel, sorption properties of wax treated wood were determined. The treated specimens were more resistant to wood decay fungi. Polyethylene and oxidized polyethylene wax were found to be particularly efficient. Although this treatment does not improve resistance to blue stain fungi, it reduces the sorption of water.
\end{abstract}

\section{Die Verwendung von Wachsemulsionen zur Verbesserung der Dauerhaftigkeit und der Sorptionseigenschaften von Holz}

\section{Zusammenfassung}

Seit Jahrzehnten werden Wachse fast ausschließlich zur Oberflächenbehandlung von Holz verwendet, weil sie nur schwach in das Holz eindringen. Um das Eindringverhalten zu verbessern, wurden in dieser Studie fünf verschiedene Wasseremulsionen in unterschiedlichen Konzentrationen verwendet, und zwar zwei Montanwachse, Polyethylen, Ethylen-Copolymer und oxidiertes Polyethylenwachs. Die Resistenz von wachsbehandeltem Buchenholz (Fagus sylvatica) und Fichtenholz (Picea abies) gegen Weißfäule-, Braunfäule- und Bläuepilze wurde untersucht. Daneben wurden die Sorptionseigenschaften von 
wachsbehandeltem Holz bestimmt. Die behandelten Prüfkörper waren gegen Holz zerstörende Pilze resistenter, wobei sich Polyethylen und oxidiertes Polyethylenwachs als besonders wirksam erwiesen. Zwar wird mit dieser Behandlung die Resistenz gegen Bläue nicht verbessert, jedoch wird die Wasseraufnahme reduziert.

\section{Introduction}

Despite the fact that wood has been used for construction applications for thousands of years, it remains one of the most important building materials. The first users of wood faced the same problem that people face nowadays. Wood is not durable in outdoors applications; therefore, it has to be protected in some way if used in such environment. In the pa st, most preservative solutions had biocidal properties and therefore, inhibited pest growth and development (Richardson 1993). Future solutions for the improvement of the durability of wood preservatives are designed differently. They change the structure of wood so that wood pests do not recognize it as food source (Tjeerdsma et al. 1998); or, wood moisture content is kept so low that decay processes are no longer possible (Goethals and Stevens 1994). It is believed that wax emulsions can be used in such manner as well. Treatment of wood with resin/wax water-repellent formulations greatly reduces the rate of water flow in the capillaries and significantly increases the dimensional stability of specimens exposed to wet conditions (Berninghausen et al. 2006, Kurt et al. 2008). The most important applications of waxes in wood industry are found in particleboard production. Paraffin emulsions are introduced to the particleboards reducing water uptake and improving dimensional stability (Amthor 1972, Deppe and Ernst 1996). Nowadays, wax emulsions are added to OSB boards for the same reason (Neimsuwan et al. 2008). However, there are reports that paraffin treatment can 
reduce water capillary uptake in wood as well (Scholz et al. 2009). Furthermore, wax treated wood exhibited increased compression strength and hardness (Rapp et al. 2005). In addition, wax and oil emulsion additives are incorporated into aqueous wood preservatives to reduce checking and improve the appearance of treated wood exposed outdoors as well (Evans et al. 2009).

Montan and carnauba waxes are some of the possible water repellent agents to be applied in order to improve wood durability as they are among the most resistant waxes that form thin films. Montan and carnauba wax as well as other waxes are almost non-toxic and are used for a variety of applications like for instance cosmetics (Anonymus 2005). Crude montan wax belongs to the group of naturally occurring waxes of vegetable origin such as carnauba wax or candelilla wax. Montan wax is fossilized vegetable wax extracted from lignites, principally from central German brown coal reserves west of the Elbe River. It is a mixture of chemical compounds that can be divided into three substance groups: waxes, resins, and asphaltic substances. Just like existing vegetable hard waxes such as carnauba wax, the pure wax substance in montan wax consists mainly of esters of long-chain acids with long-chain alcohols and free long-chain acids. Other components such as free wax alcohols or ketones, paraffins or terpenes are usually present in small quantities (Matthies 2001). Wax is soluble in many organic solvents, particularly aromatic or chlorinated hydrocarbons, even under moderate heating. Montan wax is used in the form of flakes, powders, pastes with solvents, or aqueous emulsions (Heinrichs 2003). One of the most important advantages of montan wax is its capability to form thin-layer resistant films (Warth 1959). One of the objects of this study was to show that this thin film could limit water penetration and as such improve performance against wood decay fungi. There are also other waxes - beside montan wax - used for the protection of concrete against 
stains, particularly polyethylene, ethylene copolymer and oxidized polyethylene wax. Some of those waxes are already being used for car and plastic polishing (Erhuai 2008), as they protect the surface against salt, dust and other pollutants. Another important application is the protection of concrete walls and facades against weathering, staining etc. It is believed that they can form a film on the wood surface as well as cell lumen. This enables faster water removal and decreases water sorption and desorption which results in an improved dimensional stability of wood. Dry wood will be less susceptible to fungal decay. Until now, wax (bee and paraffin waxes) has predominately been used for surface coatings (Burger 2006). It was dissolved in an organic solvent or melted prior use. However, melted waxes are only of minor importance as they do not penetrate deeper into the wood and remain on the surface of the treated material for most of the treatments. A second treatment of wood with melted waxes requires special equipment, it is expensive and there is an increased risk of fire (Scholz et al. 2009). On the other hand, organic solvents are becoming less and less desired due to environmental issues. The authors intention is to prepare wax emulsions which will penetrate deeper into the wood and, therefore, protect it against fungal decay. To the authors` knowledge nothing has been reported on wax use in the field of wood protection.

\section{Material and methods}

\section{Treatment solutions used}

For impregnation, five types of wax emulsions of various concentrations were used, namely two emulsions of montan wax (LGE, MW1), one emulsion of polyethylene (WE1), one emulsion of ethylene copolymer (WE3) and one emulsion of oxidized polyethylene (WE6) wax. The solutions are commercially 
available and produced by Samson (Slovenia) and BASF (Germany). Concentrations (dry content) and basic properties of the wax emulsions can be seen in Table 1. In order to elucidate the penetration of wax emulsions to wooden specimens, the uptake of emulsions and the retention of waxes were determined gravimetrically. For retention measurements, samples were dried at $103{ }^{\circ} \mathrm{C}$ for 24 hours, and their masses were determined before and after impregnation, and then the retention was calculated. This gravimetrically determined retention of wax was compared to the theoretical retention calculated from the uptake of solution and the concentration of wax in the emulsion.

\section{Wood decay test}

Resistance of wood impregnated with various wax emulsions against wood decay fungi was determined according to EN 113 procedure (EN 113:989). Specimens were treated with various wax emulsions prior fungal exposure (vacuum -70 mbar; $20 \mathrm{~min}$; pressure - 9.5 bar; $60 \mathrm{~min}$; vacuum - $70 \mathrm{mbar}$; $10 \mathrm{~min}$ ), as can be seen in Table 1. Wax treated specimens were air dried for four weeks. Steam sterilized, impregnated and unimpregnated wood specimens were exposed to three brown rot (Antrodia vaillantii, Serpula lacrymans and Gloeophyllum trabeum) and three white rot fungi (Trametes versicolor, Pleurotus ostreatus and Hypoxylon fragiforme). Beech wood (Fagus sylvatica) specimens were exposed to white rot and Norway spruce (Picea abies) specimens to brown rot fungi. After 16 weeks of fungal exposure, specimens were isolated and mass losses were gravimetrically determined and expressed in percentages.

\section{Blue stain and moulds test}

Scots pine (Pinus sylvestris) wood specimens were surface brushed with various wax emulsions (Table 2). Their resistance was determined according to EN 152-1 
procedure (EN 152-1:1996). The uptake of wax emulsions was approximately $200 \mathrm{~g} / \mathrm{m}^{2}$. After brushing, samples were left to dry for 3 weeks. Half of the samples were exposed to blue stain fungi, while the other half was exposed to moulds for 6 weeks according to the requirements of EN 152-1:1996. Aureobasidium pullulans and Sclerophoma pithyophila were used to test blue stain organisms. Fusarium solani, Gliocladium viride, Penicillium expynsum, and Penicillium janthinellum were used for testing mould organisms. Resistance against disfiguring fungi was estimated visually according to EN 152-1:1996. Additionally, color change was determined as well and expressed in the CIELab color system.

\section{Sorption properties}

Only LGE emulsion was used for the determination of sorption properties. There were two types of tests performed to determine sorption properties. In the first one, impregnated specimens were conditioned in water container or in a high humidity chamber, and their masses were monitored. In the second set of experiments, a tensiometer was used.

The first set of sorption experiments were performed on Norway spruce wood specimens $\left(1.5 \times 2.5 \times 5.0 \mathrm{~cm}^{3}\right)$ with end sealed (epoxy coating) axial surfaces. They were impregnated (vacuum - 70 mbar; $20 \mathrm{~min}$; pressure - 9.5 bar; $60 \mathrm{~min}$; vacuum - 70 mbar; $10 \mathrm{~min}$ ) with LGE emulsions of two different concentrations, LGE 50 and LGE 100. After four weeks of air drying, specimens were oven dried $\left(40^{\circ} \mathrm{C}\right)$ for three days. Afterwards, half of the specimens were transferred to the chamber with a relative air humidity of $82 \%$. The masses of the specimens were monitored daily for six weeks. The second half of the specimens were immersed in distilled water. The masses of the specimens were monitored for three weeks 
after predetermined periods shown in Figure 2. All moisture contents given are based on dry mass with wax.

In the second part of experiments, Norway spruce wood specimens of the following size $2.0 \times 3.0 \times 4.0 \mathrm{~cm}^{3}(\mathrm{~T} \times \mathrm{R} \times \mathrm{A})$ were utilized. The measurements were carried out at room temperature $\left(20^{\circ} \mathrm{C}\right)$ at a $\mathrm{RH}$ of $40-50 \%$ on a Krüss Processor Tensiometer K100. Axial surfaces of the specimens were positioned such that in contact with water, and afterwards their masses were measured continuously for $200 \mathrm{~s}$. Each curve in Figure 3 is an average value of 10 measurements.

\section{Results and discussion}

Wax emulsions used for impregnation in this experiment had different dry contents. They varied between 5.3\% (LGE 50) and 23.1\% (MW1 50) (Table 2). The influence of dry content on the properties of the emulsions, predominately viscosity, is significant. However, viscosity is also influenced by other parameters. The highest viscosity was observed for the WE3 emulsion, where a considerably higher viscosity is reported compared to the other waxes with a similar or even higher dry content. All emulsions applied, with the exemption of LGE, have a rather high viscosity. Their penetration is presumably more limited compared to the penetration of aqueous solutions. In general, no difference was observed between the uptakes of preservative solution for beech wood specimens. Those specimens in average retained $650 \mathrm{~kg} / \mathrm{m}^{3}$ of wax emulsions. However, considerably higher variations in retentions were observed for spruce wood specimens. Specimens impregnated with LGE 50 wax emulsion retained 570 $\mathrm{kg} / \mathrm{m}^{3}$ of emulsion, while parallel specimens that were treated with the WE6 50 emulsion up to $340 \mathrm{~kg} / \mathrm{m}^{3}$ of wax emulsion was retained (Table 2). It is presumed 
that the main reason for the observed effect could be a better impregnability of beech wood compared to spruce wood. It seems that the ability to penetrate into spruce wood specimens is in tight correlation with the dry content of wax emulsions applied. For specimens that were impregnated with emulsions of higher concentration, lower uptakes of preservative solutions were determined than for parallel specimens preserved with emulsions with a lower dry content (Figure 1). Although the emulsion particles (disperse phase) are rather small (100 $\mathrm{nm}$ ), they are too big to penetrate into the cell wall. Lignified wood cell walls contain a nanocapillary network that is $1-10 \mathrm{~nm}$ in size (Fujino and Itoh 1998). Therefore, wax is deposited in the cell lumen only (Lesar et al. 2008).

The fact that particles in the emulsion are too big to penetrate into the cell wall is reflected in the differences between gravimetrically determined wax retentions and theoretical wax retentions calculated from the solution uptake and dry content (Table 2). These differences varied between $2 \%$ and $23 \%$ in beech wood specimens and between $12 \%$ and $74 \%$ in spruce specimens. This result shows a better impregnability of beech wood. However, differences in retention are most evident in spruce specimens impregnated with the WE3 emulsion, where $73 \%$ less wax was determined than was presumed from the uptake of solutions. It is presumed that during the impregnation process, water penetrated deeper into the specimens while wax remained on the surface.

A more important object of this research was to determine the effect of wax treatment on performance against wood decay fungi. All wood decay fungi used in this experiment were vital, as mass losses of control specimens were higher than $20 \%$, with the exception of $A$. vaillantii where control specimens only lost $16.9 \%$. This fungal strain is known as a less aggressive, but on the other hand very effective degrader of impregnated and modified wood (Table 3). 
Mass losses of specimens impregnated with different wax emulsions varied from 2\% (WE6 50; T. versicolor) up to 32\% (WE3 50; H. fragiforme). As seen in Table 1, it can be concluded that applied wax emulsions can slow down wood fungi to grow. Among the treatments the WE3 wax emulsion (emulsion of ethylene copolymer wax) was found to be least effective. This emulsion was the most viscose one among the emulsions tested, and its penetration into the wooden specimens was the worst. It should be considered that most of the wax remained on the surface of the treated specimens and therefore did not have prominent influence on the performance of the impregnated wood (Table 2). Additionally, specimens impregnated with montan wax emulsions (LGE and MW) were decayed less than the control ones. Among the fungi tested, montan wax emulsions were found to be the least effective ones against G. trabeum. During the 16 weeks of exposure to the fungi mentioned above, the control specimens lost $35.7 \%$ while the specimens impregnated with montan wax emulsions lost between $26.1 \%$ and $15.8 \%$ depending on the concentration of montan wax in emulsions. Specimens impregnated with emulsions of higher concentrations were better protected against wood decay fungi than specimens impregnated with lower concentrations of montan wax (Table 3). Among the tested wax emulsions, emulsions WE1 (emulsion of polyethylene wax) and WE6 (emulsion of oxidized polyethylene wax) proved to be the most effective agents for the protection of wood against wood rotting fungi. For example, after 16 weeks of exposure to $G$. trabeum, mass losses of spruce wood specimens impregnated with the WE1 50 emulsion were only $3.8 \%$ and $5.7 \%$ after exposure to $S$. lacrymans. This treatment was effective against white rot species as well. P. ostreatus caused mass loss of $8.4 \%$, while $T$. versicolor decayed only $3.9 \%$ of impregnated specimens (Table 3 ). Unfortunately, WE1 and WE6 emulsions were not that effective against $A$. 
vaillantii and $H$. fragiforme. A comparison of the dry content data and mass losses after fungal decay revealed that there is no statistically significant correlation between those two parameters. This indicates that fungicidal properties of impregnated wood depend more on the properties of wax than those of dry content. $\mathrm{pH}$ is one of the mechanisms which could explain the efficacy of the wax treated wood. Wood treated with wax emulsions WE1 and WE6 with $\mathrm{pH}$ around 9 exhibited a better performance against wood decay fungi than montan wax treated wood. It is well known that fungi prefer slightly acidic substrates rather than alkaline ones (Schmidt 2006). However, resistance of wax treated wood to wood decay fungi cannot be explained by $\mathrm{pH}$ dependent mechanisms, as wax emulsion WE3 has alkaline $\mathrm{pH}$, but fungi can degrade WE3 treated wood to similar extent to the LGE ones. The other mechanism that potentially improves the performance of the wax treated wood against wood decay fungi is film/barrier formed in the cell lumina and on the surface of the specimens. This barrier slows down moisturizing, the diffusion of enzymes and degradation products between hyphen and wood. It is presumed that this mechanism only slows down the degradation processes and does not stop them. Therefore it is suggested that the EN 113 test should be prolonged to overcome the influence of a slow down diffusion. This experimental issue is overcome in long lasting field tests. The preliminary results of the double layer field trial showed that after two and a half years of natural exposure there is considerable decay at the control unimpregnated spruce wood specimens. After eight months of exposure, the first fruiting bodies of the Gloeophyllum sp. were noticed. On the other hand, there were no signs of decay on the parallel spruce wood treated with LGE, WE1 or WE6 emulsions. This is additional evidence that wax treated wood exhibits a better performance against wood decay fungi than untreated wood. As already explained, the authors believe 
that the most important reason for improved performance of wax treated wood in double layers is due to moisture relating effects. Moisture content of wax treated wood was lower. Therefore they are les susceptible to decay.

Unfortunately, wax emulsions do not improve the resistance of wax treated wood against blue stain and mould fungi. Both control and impregnated specimens were completely stained after blue stain exposure as well as after exposure to moulds. The surface of the specimens was covered with stains that covered more than $60 \%$ of the surface (Table 4). Despite the fact that both specimens exposed to blue stains and moulds were estimated with the same mark (3), the color change $(\Delta \mathrm{E})$ that can be seen in Table 4 clearly shows that control specimens exposed to the blue stain fungi were considerably darker than the ones exposed to mould fungi. A similar effect can be observed for impregnated specimens as well. Unfortunately, none of the wax emulsions improved the resistance of the treated wood against staining organisms. A visual estimation showed some traces of inhibitory properties. All wax emulsions, with the exception of WE3, slightly inhibit moulding. This effect was not expressed for all specimens but only for some of them. The effect of waxes against blue staining was even less prominent. The color analysis of the wax treated specimens exposed to staining fungi showed an even more negative influence of waxes on the resistance against staining. This analysis showed that there might be fewer individual stains on the surface of the specimens, and there was less surface covered with stains, but those stains were darker than the stains on control specimens. There might be a better resistance of wax treated wood observed if the specimens had been impregnated instead of surface treated. 
The impregnation of spruce wood with waxes has an effect on sorption properties of impregnated wood as well. An increase of the moisture content of the LGE impregnated specimens was slower compared to the specimens conditioned in humid air as well as the ones immersed in water. The moisture content (MC) of wood impregnated with the LGE emulsion after 60 days of conditioning was also lower than the $\mathrm{MC}$ of control specimens. It can be seen from Figure 2a that the MC of LGE 100 impregnated specimens at RH of $80 \%$ was $12.1 \%$, while an $15 \%$ higher moisture content was observed for the control specimens after 60 days of conditioning. The MC mentioned above was even reached after 18 days for control specimens. It can be seen in Figure $2 \mathrm{a}$ that even after 60 days of conditioning of specimens impregnated with the LGE 100 emulsion, they did not reach their equilibrium moisture content. The MC of LGE treated specimens was still slightly increasing even after two months of conditioning. This indicates that the LGE wax can form a film on wood that is able to significantly slow down the adsorption. A similar effect was observed during the wetting of wooden specimens (Figure 2b). The uptake of water of specimens impregnated with LGE emulsions was slower than that of control specimens. The final MC of control specimens was 96\%, while LGE impregnated specimens absorbed approximately $17 \%$ less water. It is presumed that there are three reasons for this. Firstly, waxing makes the surface of the specimens more hydrophobic. Secondly, the cell lumina were at least partly filled with waxes and this physically prevents moisturizing. Finally, there were thin film-barriers formed on the surface of the wooden specimens, which slow down water movement.

This hydrophobic effect of the montan wax can also be seen from the measurement of the water uptake using tensiometer (Figure 3). During this test, 
axial surfaces of wooden specimens were positioned such that in contact with water. Afterwards, the water uptake was gravimetrically measured. The uptake of water in control spruce wood specimens was relatively fast. Within $200 \mathrm{~s}$, specimens from axial surfaces $\left(6 \mathrm{~cm}^{2}\right)$ retained more than $0.8 \mathrm{~g}$ of water. The shape of the uptake is clearly logarithmical. The uptake of water is faster in the beginning and then slows down. Approximately half of the water was absorbed after $30 \mathrm{~s}$ (Figure 3). The water uptake in the montan wax impregnated specimens was considerably lower for both specimens impregnated with pure LGE emulsion (LGE 100) and for the ones impregnated with the same emulsion of a lower concentration (LGE 50). The shape of the water uptake curve for LGE treated specimens significantly differs from the curve observed for control specimens. The water uptake decreased during the initial stage. It reached its maximum after $12 \mathrm{~s}$ (LGE 100) or $16 \mathrm{~s}$ (LGE 50), and then appeared to decrease rapidly before it started increasing again after $50 \mathrm{~s}$ (Figure 3). This pattern is characteristic for hydrophobic surfaces (Rowel and Banks 1985). There was no decrease in the water uptake, but this pattern is a result of the hydrophobic properties and the lifting power of the water in contact with the surface where contact angles are higher than 90 degrees. However, after $200 \mathrm{~s}$ the LGE 50 treated spruce specimens took eight times less water up than the control ones, while the uptake in LGE 100 treated wood was even lower. This is an additional proof that montan wax treatment improves the sorption properties of wax treated wood.

\section{Conclusion}

The uptake of wax emulsion based solutions in spruce wood specimens was influenced by dry content and viscosity of the wax emulsions applied. Some of the wax emulsions tested do considerably slow down fungal degradation, but do not 
stop it. Emulsions of oxidized polyethylene wax (WE6) were found to be particularly effective. Unfortunately, treatment of wood with waxes does not prevent staining. One of the positive properties of treated wood is that the impregnation of wood with emulsion of montan wax reduces water uptake of the wax treated wood. It is believed that wax emulsions have the potential to be used for wood protection in less hazardous outdoor applications.

\section{Acknowledgements}

The authors would like to acknowledge the Slovenian Research Agency for financial support in the frame of the projects L4-0820-0481 and P4-0015-048. We appreciate the technical support of Gregor Smrdelj, Žiga Melanšek and Jože Avguštinčičc.

\section{References}

Amthor J (1972) Paraffin dispersions for waterproofing of particle board. Holz Roh- Werkst. 30(11): 422-425

Anonymus (2005) Poligen MW1, Technical information. www.basf.de, Accessed 2.10.2008 Berninghausen CG, Rapp AO, Welzbacher CR. (2006) Impregnating agent, process for impregnating of dried and profiled wood, and wood product impregnated therewith, patent EP1660285

Burger HJ (2006) Method for introducing wax in thermal wood, patent EP1646483

Evans PD, Wingate-Hill R, Cunningham RS. (2009) Wax and oil emulsion additives: How effective are they at improving the performance of preservative-treated wood? Forest Prod J. 59(12): 66-70

Erhuai L (2008) Wax polish and preparation method thereof, patent CN101148565 European Committee for Standardization EN 113 (1989). Wood preservatives; Determination of the toxic values against wood destroying basidiomycetes cultured an agar medium European Committee for standardization EN 152-1 (1996) Test methods for determining the protective effectiveness of a preservative treatment against blue stain in service - Part 1: Brushing procedure

Fujino T, Itoh T (1998) Changes in the three dimensional architecture of the cell wall during lignification of xylem cells in Eucalyptus tereticornis. Holzforschung 52: 111-116 Goethals P, Stevens M (1994) Dimensional stability and decay resistance of wood upon modification with some new type chemical reactants. The International Research Group on Wood Preservation, Document, IRG/WP 94-40028, p. 14 
Heinrichs FL (2003) Montan wax. In: Bhonet M. (ed) Ullman's encyclopedia of industrial chemistry, Vol. 39 -chapter 3. Eds. Wiley-VCH, Weinheim, pp. 154-159.

Kurt R, Krause A, Militz H, Mai C (2008) Hydroxymethylated resorcinol (HMR) priming agent for improved bondability of wax-treated wood. Holz Roh- Werkst. 66(5):333-338.

Lesar B, Zupančič M, Humar M (2008) Microscopic analysis of wood impregnated with aqueous montan wax emulsion. LesWood 60(9): 320-326.

Matthies L. (2001) Natural montan wax and its raffinates. Eur J of Lipid Sci and Tech; 103:239248.

Neimsuwan T, Wang S, Via BK. (2008) Effect of processing parameters, resin, and wax loading on water vapor sorption of wood strands. Wood Fiber Sci 40(4): 495-504

Rapp AO, Beringhausen C, Bollmus S, Brischke C, Frick T, Haas T, Sailer M, Welzbacher CR. (2005) Hydrophobierung von Holz-Erfahrungen nach 7 Jahren Freilandtest. In: 24th

Holzschutztagung der DGFH, Leipzig, Germany, 157-170.

Richardson BA (1993) Wood Preservation. Second edition. E \& FN Spon, London, Glasgow

Rowell RM, Banks WB (1985) Water Repellency and Dimensional Stability of Wood. Madison

U.S. Forest Products Laboratory. FPL 50-RP. pp. 24

Schmidt O. (2006) Wood and Tree Fungi Biology, Damage, Protection, and Use. Springer Berlin Heidelberg, New York, pp. 329

Scholz G, Krause A, Militz H. (2009) Capillary Water Uptake and Mechanical Properties of Wax Soaked Scots Pine.in: $4^{\text {th }}$ European Conference on Wood Modification, Stockholm, pp. 209- 212 Tjeerdsma BF, Boonstra M, Militz H, (1998) Thermal modification of non-durable wood species 2. Improved wood properties of thermally treated wood. The International Research Group on Wood Preservation, Document, IRG/WP 98-40124, p. 10

Warth AH (1959) The chemistry and Technology of Waxes. Reinhold Publishing Corporation, New York (USA) 


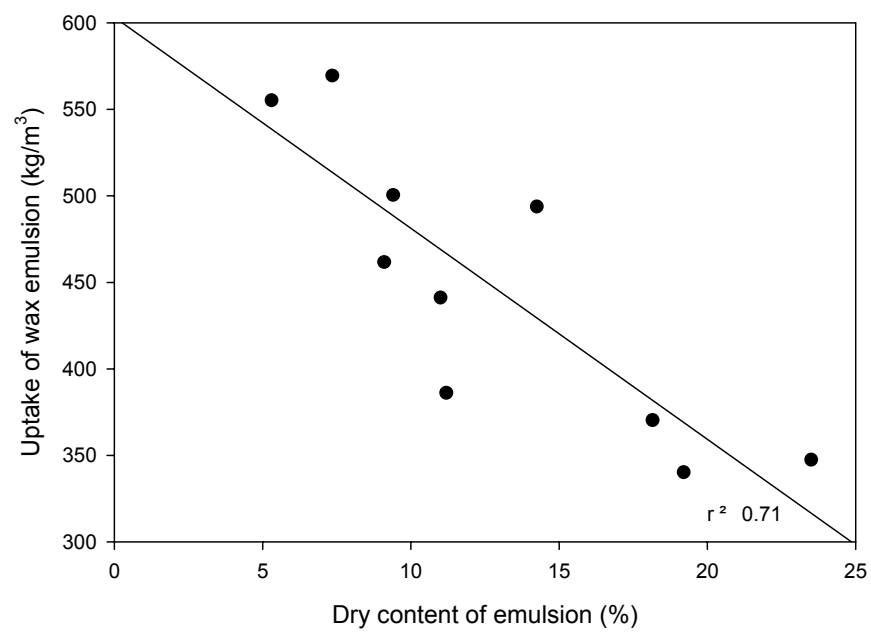

Figure 1: Correlation between dry contents of the emulsion and uptake of preservative solutions in spruce wood specimens 

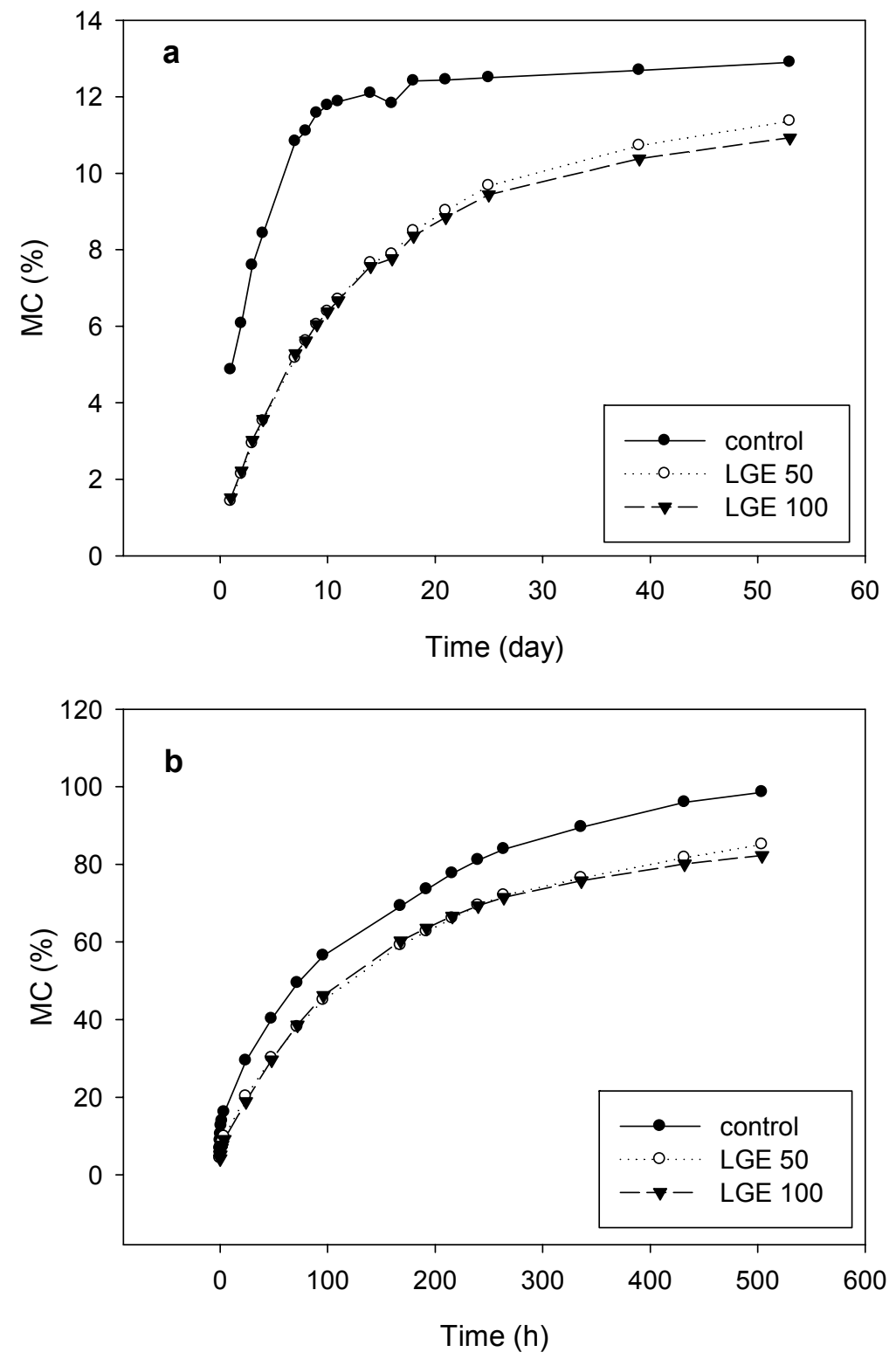

Figure 2: Changes in moisture contents (MC) of the control specimens and specimens treated with LGE wax emulsions in atmosphere with RH of $82 \%$ (a) or during immersion in water (b). 


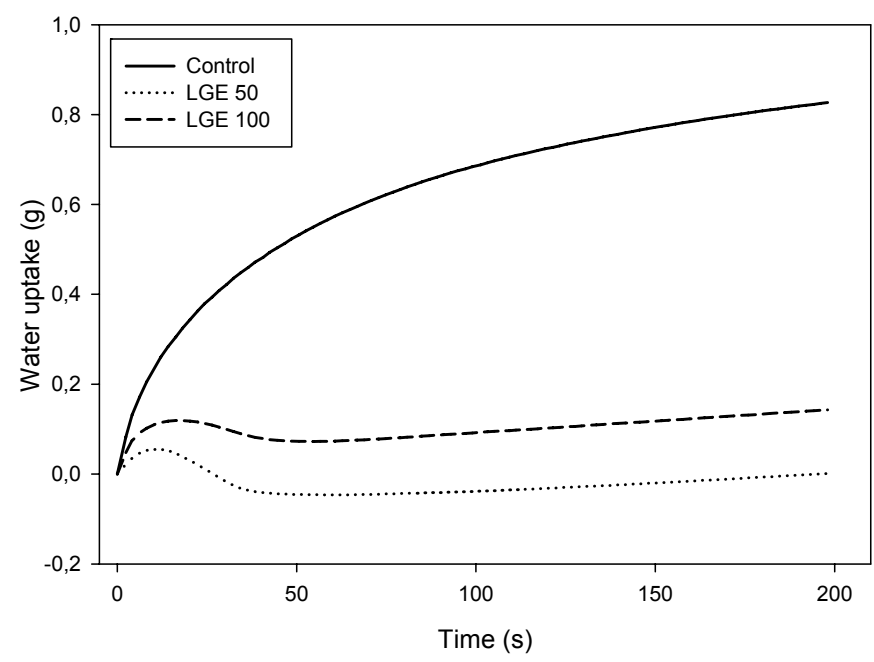

Figure 3: Water uptake of axial surfaces of the montan wax (LGE) and control specimens expressed in grams. Uptake was determined with tensiometer. 
Ejwwp425 source

Table 1: Selected properties of the undiluted/commercial wax emulsions used

\begin{tabular}{|c|c|c|c|c|c|c|c|}
\hline $\begin{array}{l}\text { Preservative } \\
\text { solution }\end{array}$ & $\begin{array}{l}\text { Dry } \\
\text { content } \\
(\%)\end{array}$ & $\mathrm{pH}$ & $\begin{array}{l}\text { Emulsion } \\
\text { viscosity } \\
\left(4 \mathrm{~mm} 23^{\circ} \mathrm{C}\right) \\
\text { ISO } 2431 \\
\text { (s) }\end{array}$ & $\begin{array}{l}\text { Density } \\
\left(\mathrm{g} / \mathrm{m}^{3}\right)\end{array}$ & $\begin{array}{l}\text { Melting } \\
\text { point of } \\
\text { solids }\left({ }^{\circ} \mathrm{C}\right)\end{array}$ & $\begin{array}{l}\text { Average } \\
\text { particle } \\
\text { size }(n m)\end{array}$ & Emulsifier system \\
\hline LGE & 11.4 & 5.5 & 13 & 1.00 & $76-80$ & 100 & n.a. \\
\hline MW1 & 46.2 & 4.6 & 25 & 1.01 & 78 & 100 & Nonionic \\
\hline WE1 & 36.4 & 9.9 & $20-36$ & 1.00 & $130-135$ & 100 & Nonionic/anionic \\
\hline WE3 & 28.4 & 9.7 & $85^{*}$ & 1.00 & 85 & 100 & n.a. \\
\hline WE6 & 38.2 & 8.9 & $20-60$ & 1.00 & $126-133$ & 100 & Nonionic/anionic \\
\hline
\end{tabular}


Ejwwp425 source

Table 2: Uptake of wax emulsions during impregnation process with regard to concentration, wood species and composition of solution. In addition, there are gravimetrically determined retention and differences between theoretically calculated and actual retention.

\begin{tabular}{|c|c|c|c|c|c|c|c|c|}
\hline \multirow[b]{2}{*}{$\begin{array}{l}\text { Wax } \\
\text { emulsion }\end{array}$} & \multirow[b]{2}{*}{$\begin{array}{l}\text { Conc. } \\
(\%)\end{array}$} & \multirow[b]{2}{*}{$\begin{array}{l}\text { Dry } \\
\text { cont. (\%) }\end{array}$} & \multicolumn{3}{|c|}{ Spruce wood } & \multicolumn{3}{|c|}{ Beech wood } \\
\hline & & & $\begin{array}{l}\text { Uptake of } \\
\text { wax emulsion } \\
\left(\mathrm{kg} / \mathrm{m}^{3}\right)\end{array}$ & $\begin{array}{l}\text { Retention } \\
\text { of wax } \\
\left(\mathrm{kg} / \mathrm{m}^{3}\right)\end{array}$ & $\begin{array}{l}\text { Difference } \\
\text { between } \\
\text { theoretical } \\
\text { and actual } \\
\text { wax } \\
\text { retention } \\
(\%)\end{array}$ & $\begin{array}{l}\text { Uptake of } \\
\text { wax } \\
\text { emulsion } \\
\left(\mathrm{kg} / \mathrm{m}^{3}\right)\end{array}$ & $\begin{array}{l}\text { Retention } \\
\text { of wax } \\
\left(\mathrm{kg} / \mathrm{m}^{3}\right)\end{array}$ & $\begin{array}{l}\text { Difference } \\
\text { between } \\
\text { theoretical } \\
\text { and actual } \\
\text { wax } \\
\text { retention } \\
(\%)\end{array}$ \\
\hline \multirow[t]{2}{*}{ LGE } & 50 & 5.3 & 555 & 26 & 12 & 644 & 34 & 2 \\
\hline & 100 & 11.4 & 386 & 32 & 27 & 647 & 67 & 10 \\
\hline \multirow[t]{2}{*}{ MW1 } & 25 & 10.9 & 441 & 41 & 16 & 639 & 58 & 17 \\
\hline & 50 & 23.1 & 347 & 53 & 34 & 662 & 126 & 18 \\
\hline \multirow[t]{2}{*}{ WE1 } & 25 & 9.4 & 500 & 39 & 16 & 641 & 56 & 6 \\
\hline & 50 & 18.2 & 370 & 52 & 24 & 668 & 113 & 7 \\
\hline \multirow[t]{2}{*}{ WE3 } & 25 & 7.3 & 569 & 30 & 29 & 659 & 40 & 17 \\
\hline & 50 & 14.2 & 494 & 18 & 74 & 663 & 72 & 23 \\
\hline \multirow[t]{2}{*}{ WE6 } & 25 & 9.4 & 462 & 35 & 19 & 655 & 56 & 9 \\
\hline & 50 & 19.1 & 340 & 45 & 31 & 670 & 110 & 14 \\
\hline
\end{tabular}


Ejwwp425_source

Table 3: Mass loss of the wax treated spruce and beech wood specimens exposed to various wood decay fungi according to EN 113 procedure.

\begin{tabular}{|c|c|c|c|c|c|c|c|}
\hline \multirow{3}{*}{$\begin{array}{l}\text { Wax } \\
\text { emulsion }\end{array}$} & \multirow{3}{*}{$\begin{array}{l}\text { Conc. } \\
(\%)\end{array}$} & \multicolumn{6}{|c|}{ Wood decay fungi } \\
\hline & & G. trabeum & $\begin{array}{l}\text { A. } \\
\text { vaillantii }\end{array}$ & S. lacrymans & P. ostreatus & $\begin{array}{l}T . \\
\text { versicolor }\end{array}$ & H. fragiforme \\
\hline & & & & Mass & loss (\%) & & \\
\hline \multirow[t]{2}{*}{ LGE } & 50 & 26.1 & 11.2 & 18.8 & 15.2 & 24.6 & 28.5 \\
\hline & 100 & 24.7 & 14.8 & 17.8 & 11.4 & 20.4 & 23.7 \\
\hline \multirow[t]{2}{*}{ MW1 } & 25 & 22.2 & 10.4 & 17.2 & 13.2 & 21.4 & 24.4 \\
\hline & 50 & 15.8 & 11.7 & 13.1 & 7.3 & 13.9 & 20.7 \\
\hline \multirow[t]{2}{*}{ WE1 } & 25 & 6.0 & 7.3 & 12.2 & 14.8 & 20.8 & 30.9 \\
\hline & 50 & 3.8 & 10.9 & 5.7 & 8.4 & 3.9 & 18.3 \\
\hline \multirow[t]{2}{*}{ WE3 } & 25 & 21.2 & 16.1 & 27.4 & 13.7 & 30.6 & 27.6 \\
\hline & 50 & 13.6 & 16.2 & 30.0 & 20.4 & 22.3 & 32.4 \\
\hline \multirow[t]{2}{*}{ WE6 } & 25 & 23.0 & 11.3 & 7.1 & 10.0 & 17.9 & 22.4 \\
\hline & 50 & 7.7 & 7.8 & 3.2 & 8.9 & 1.6 & 21.7 \\
\hline Control & 1 & 35.7 & 16.9 & 40.2 & 23.0 & 32.0 & 32.7 \\
\hline
\end{tabular}


Ejwwp425_source

Table 4: Resistance of pine wood specimens to blue stain and mould fungi

determined according to EN 152-1 procedure.

\begin{tabular}{lrlrll}
\hline $\begin{array}{l}\text { Wax } \\
\text { emulsion }\end{array}$ & $\begin{array}{l}\text { Conc. } \\
\text { (\%) }\end{array}$ & $\begin{array}{l}\text { Visual } \\
\text { estimation } \\
\text { - }\end{array}$ & $\begin{array}{l}\text { Visual } \\
\text { estimation } \\
\text { moulds }\end{array}$ & $\begin{array}{l}\Delta \text { blue stain } \\
\text { after exposure to } \\
\text { moulds }\end{array}$ & $\begin{array}{l}\Delta \mathrm{E} \text { - Color change after } \\
\text { exposure to blue stain } \\
\text { fungi }\end{array}$ \\
\hline LGE & 50 & 2.8 & 3 & 13.1 & 40.2 \\
& 100 & 2.4 & 2.8 & 12.0 & 39.8 \\
MW A & 25 & 2.3 & 3 & 8.3 & 32.9 \\
& 50 & 2.4 & 3 & 8.3 & 39.2 \\
WE 1 A & 25 & 2.4 & 3 & 11.1 & 29.2 \\
& 50 & 2.9 & 2.6 & 12.2 & 21.1 \\
WE 3 A & 25 & 3 & 2.8 & 18.1 & 41.6 \\
& 50 & 3 & 3 & 18.6 & 32.9 \\
WE 6 A & 25 & 2.6 & 2.6 & 12.0 & 32.3 \\
& 50 & 2.25 & 3 & 27.2 & 25.9 \\
Control & 1 & 3 & 3 & 9.1 & \\
\hline
\end{tabular}


Abb. 1

Korrelation zwischen Trockengehalt der Emulsion und Schutzmittelaufnahme in Fichtenholzprüfkörpern

Abb. 2

Änderung der Holzfeuchte (MC) der Kontrollproben und der mit LGE

Wachsemulsionen behandelten Prüfkörper a) in einer Umgebung von 82\% rel.Lf. oder b) bei Wasserlagerung

Abb. 3

Wasseraufnahme über die Hirnholzflächen von mit Montanwachs (LGE) behandelten sowie Kontrollproben, in Gramm. Die Wasseraufnahme wurde mit einem Tensiometer gemessen.

Tabelle 1

Verschiedene Eigenschaften der verwendeten unverdünnten/handelsüblichen Wachsemulsionen

Tabelle 2

Aufnahme von Wachsemulsionen während der Imprägnierung in Abhängigkeit von der Konzentration, der Holzart und der Zusammensetzung der Lösung. Zusätzlich sind die gravimetrisch bestimmte Einbringmenge sowie die Unterschiede zwischen theoretisch berechneter und tatsächlicher Einbringmenge angegeben.

Tabelle 3

Masseverluste der wachsbehandelten Fichten- und Buchenholzprüfkörper nach Befall mit verschiedenen Holz zerstörenden Pilzen gemäß EN 113.

Tabelle 4

Resistenz der Kiefernholzprüfkörper gegen Bläue und Schimmelpilze gemäß EN 152-1 bestimmt 